The $B D J$ News section accepts items that include general news, latest research and diary events that interest our readers. Press releases or articles may be edited, and should include a colour photograph if possible. Please direct your correspondence to the News Editor, Arveen Bajaj at the BDJ, The Macmillan Building, 4 Crinan Street, London N19XW or by email to bdj@bda.org

\section{Gene breakthrough}

Researchers have identified the genes in periodontal disease bacteria that allow them to invade and infect human arterial cells, offering one possible explanation for a perceived connection between gum and heart disease.

Scientists from the University of Florida, Gainesville found that Porphyromas gingivalis, an important bacterium that causes gum disease, is also linked to cardiovascular disease. In their study they identified and studied four genes of $P$. gingivalis that allow it to infect and survive inside artery cells.

Paulo Rodrigues, a researcher on the study and his colleagues had previ ously discovered that $P$. gingivalis had the ability to invade and survive inside human artery cells. In this study they created four strains of the bacterium, each with a different gene mutated to disable it, and tested its ability to invade and survive in artery cells compared to a fully functioning strain of $P$. gingivalis.

"Ourstudy showed that all four mutated strains were defective in invasion of the artery cells and that their ability to survive inside the cells was diminished. These results show that these four genes play a role in the invasion and survival of $P$. gingivalis inside artery cells," said Rodrigues. "The knowledge of how this pathogenic bacterium interacts with artery cells is important and may

\begin{tabular}{|l} 
ment of therapeu- \\
tics and diagnostic \\
tools for the detec- \\
tion and possibly \\
prevention of heart \\
diseases caused by \\
this association." \\
The research was \\
presented at the \\
106th General Meet- \\
ing of the American \\
Society for Micro- \\
biology in Orlando, \\
Florida last month.
\end{tabular}

\title{
Dental team scoops award
}

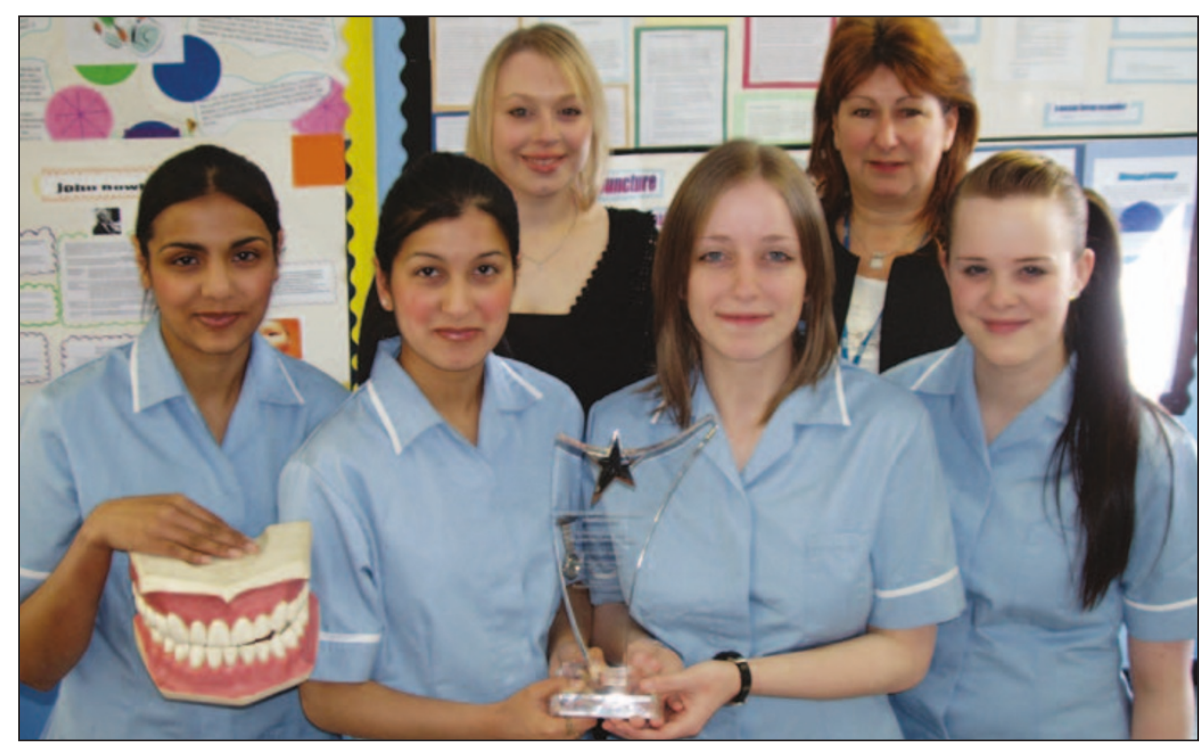

A dental nurse cadet scheme has won an award in the Positive Performance section of the 2006 Greater Manchester NHS awards. The scheme sees cadets spending 12 weeks at The Oldham College, and then four days each week in surgeries to learn by a dentist's side. It is part of a national push to attract more young people to consider careers in NHS dentistry and to develop a recognised training pathway for dental nurses prior to registration. In the awards the scheme was up against tough competition across various areas of health, such as women and children's care, pain management and support for people with learning disabilities. The awards were run by the Greater Manchester Strategic Health Authority and the aim was to recognise teams working in local health and social care organisations. Pictured above, Cadets Rizwana Bashir, Safia Hussain, Rebekah Greenhalgh, Martine McCusker. Back row, Kelly Nicol college course co-ordinator and Julie Jones, PCT course co-ordinator.

\section{New GDC Chief Executive appointed}

The General Dental Council (GDC) has appointed a new Chief Executive and Registrar. Duncan Rudkin, an experienced member of the GDC's staff, with previous experience as a solicitor in the City of London, has been appointed to the post, which became vacant following the departure of Antony Townsend last month.

Mr Rudkin takes up the post with immediate effect and will oversee the opening, on 31 July, of a new register for all members of the dental team, and the implementation of changes to the GDC's fitness to practise procedures.

After qualifying from the University of Oxford, with a degree in Modern Lan- guages, he studied at the College of Law before beginning work in the City of London as a solicitor dealing with commercial dispute resolution. He joined the GDC in 1998 as Director of Legal Services,

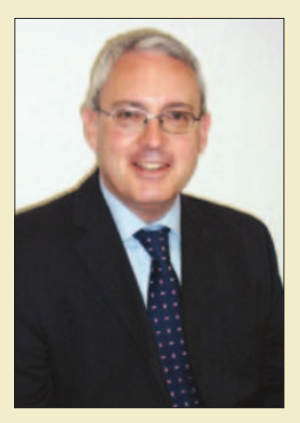
tasked with setting up the GDC's first inhouse legal department. He has since held senior management roles at the GDC, as Director of Professional Standards, Deputy Chief Executive and most recently Acting Chief Executive and Registrar. 


\section{DIARY}

July

82 nd Congress of the

European Orthodontic Society

Venue: Hofburg Congress Center,

Vienna, Austria

Date: 4-8 July 2006

Tel: $(+43 / 1) 53116-38$

Fax: $(+43 / 1) 53116-61$

Email: azmedinfo@media.co.at

\section{September}

The British Society of Paediatric Dentistry

Annual Scientific Conference

'The Art \&t the Science'

Venue: The Hilton, Leeds City

Date: 12-15 September 2006

www.bspd.co.uk/conf-2006.html

European Society for Oral Laser Applications/ Hellenic Society for Oral Laser Applications 1st Mediterranean Laser Congress

Venue: Hilton Hotel Rhodes Resort, Greece

Date: 21-23 September 2006

Email: esola2006@medacad.org

www.esola.at

FDI Annual World Dental Congress

Venue: Shenzhen, China

Date: 22-25 September 2006

Email: congress@fdiworldental.org

www.fdiworldental.org

November

British Academy of Cosmetic Dentistry's

(BACD) 2nd Annual Conference

Venue: Britannia International

Hotel, London

Date: 16-18 November 2006

Email: info@bacd.com

www.bacd.com

\section{Complaints service launched}

A new impartial service to resolve complaints about private dental care has been launched by the General Dental Council in order to help resolve complaints about private dental care as fairly and as quickly as possible.

The Dental Complaints Service will cover the whole of the UK and will be open to patients wishing to complain about any aspect of dental care, treatment or service involving any member of a dental team. Currently, NHS dental patients can use the NHS complaints process, but private patients who have not been able to resolve their complaint with a dental practice have limited options open to them. The new service seeks to plug that gap.

The service was introduced by Hew Mathewson President of the General Dental Council, Rosie Winterton MP Minister of State for Health Services and Derek Prentice Chairman of Dental Complaints Service Advisory Board.

Hew Mathewson, said, "The aim of setting up the Dental Complaints Service is to help dental patients resolve complaints about private dental care as fairly, efficiently, transparently and quickly as we can. We hope that patients will use this service to sort out problems, and avoid the expense and delays of court action. The service will also help dental professionals to improve the quality of service they provide."

Dissatisfied dental patients who call the Dental Complaints Service will first be encouraged to use their dental practice's own complaints procedures, if they have not already done so. If a complaint remains unresolved, Dental Complaints

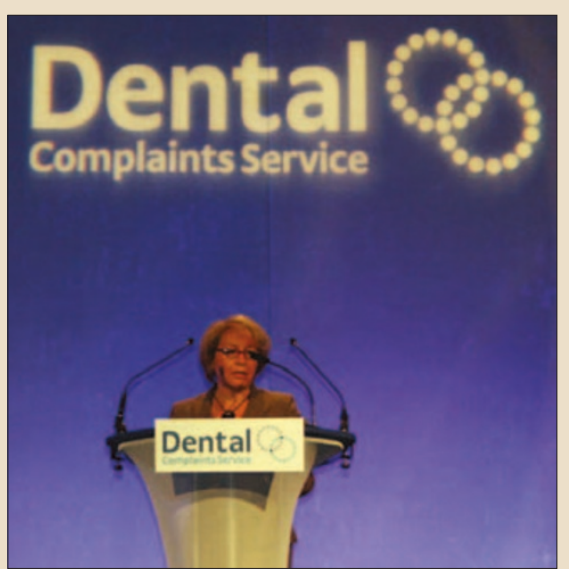

Rosie Winterton MP, Minister of State for Health Services at the launch

Service advisers will discuss it directly with the patient and dental professional concerned.

If the adviser cannot resolve matters, the complaint will go to one of a series of regional panels. The panel will meet with the dentist and complainant and recommend how best to resolve the complaint. Their emphasis will be on resolving complaints using common sense.

Serious complaints - which raise issues about patient safety and whether a practitioner should be allowed to continue practising - will continue to be dealt with by the GDC as they are now.

The Dental Complaints Service is preparing for around $2-4,000$ complaints a year from across the UK. It is hoped that around 80 per cent of these complaints will be resolved by advisers, without the need to hold a panel.

For more information visit www. dentalcomplaints.org.uk.

\section{Grant given to Egyptian students}

Ashraf Ayoub, Professor of Oral and Maxillofacial Surgery at the University of Glasgow, and Declan Millett, Professor of Orthodontics at the University of Cork, have been awarded a grant of 500,000 Euros from the European Commission Trans-European mobility scheme for university studies (TEMPUS).

The funding will allow development and modernisation of the curriculum on management of dentofacial deformities for undergraduates, postgraduates and general dental practitioners in Egypt.

It represents the largest educational grant to be awarded by the European Commission TEMPUS to the University of Glasgow, and reflects an ongoing collaboration between the Dental Schools in Glasgow and Cork to improve the quality of education and research locally, nationally and internationally.

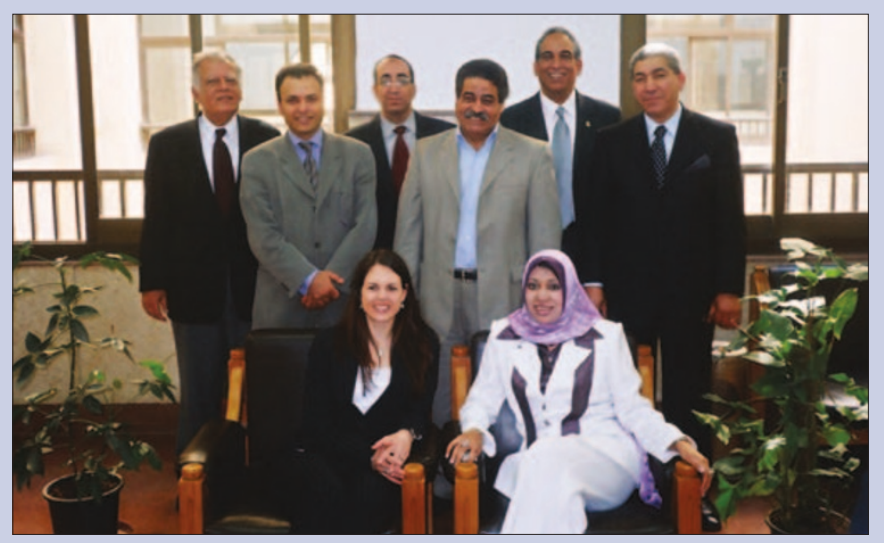

Pictured from left to right, members of the Consortium at the launch of the TEMPUS Joint European Educational Project in Cairo, Egypt, Prof. S. El Mofty, Prof. A. Ayoub, Prof. A. Sadaka, Prof. M. Lotfy, Prof. H. Nassar, Prof. A. Shoman, Mrs A. Maguire and Ms H. Helal. 


\section{Focusing on special care dentistry}

A new special care dentistry interactive learning programme has been launched to increase awareness and inform general dental practitioners of the implications of the Disability Discrimination Act.

Produced by Smile-on in association with the Department of Health, the new programme is being distributed free to every practice in England and Wales. It covers the application of the Disability Discrimination Act to dental practices, including access issues, the treatments available to the special care group, with information covering those who can be treated by a GDP and those who can be referred.

The Special Care Dentistry programme is divided into four main sections: Older People, Physical Disability, Medical Con-

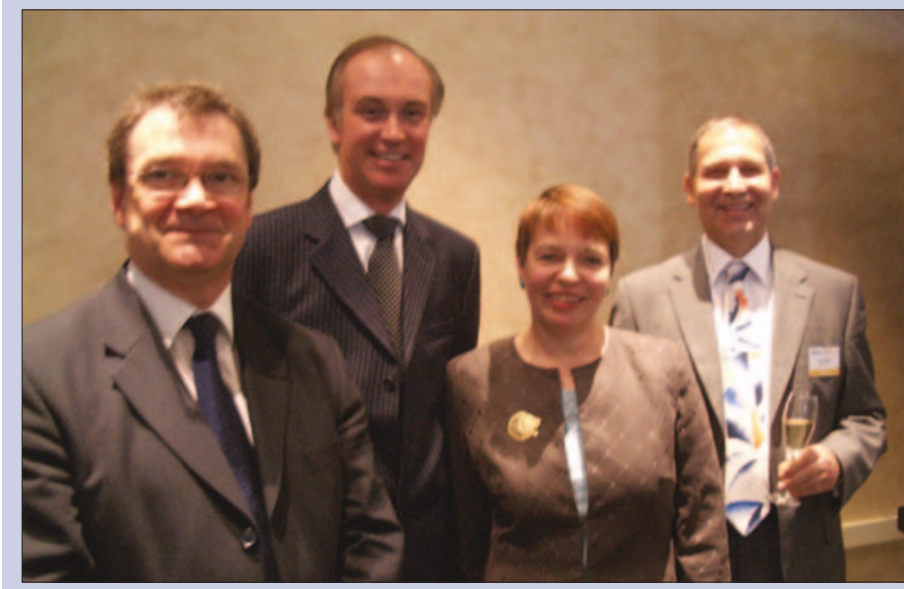

From left to right, Dr Barry Cockroft, Acting Chief Dental Officer (England), Dr Roger Davies, Consultant in Special Care Dentistry at the Eastman Dental Hospital and Institute, $\mathrm{Dr}$ Janice Fiske MBE Senior Lecturer and Consultant in Special Care Dentistry at the Kings College Dental Hospital and

Noam Tamir, CEO, Smile-on.

\section{NHS dentistry given funding boost}

NHS dental practices and their patients will benefit from a programme of capital investment of $£ 100$ million over two years announced by health minister Rosie Winterton, recently.

Designed to improve and modernise dental practices across the country, the capital investment supports dentists in modernising premises and equipment to improve services for patients, and allow Primary Care Trusts (PCTs) to give greater financial support to help dentists establish practices or to upgrade existing ones.

The investment will be made available to the NHS, through Strategic Health Authorities (SHAs), over the next two years to take forward infrastructure improvements for NHS primary dental care services. This builds on the $£ 80$ million capital investment already going towards modernising dental education establishments and supporting the 25 per cent expansion in dental training places.

Rosie Winterton said, "I have visited many dental practices over the last three years, some of which would clearly benefit from modernising their premises or upgrading their equipment. These dentists are providing services of a high quality but working in environments which could be improved with greater capital investment."

The $£ 100$ million of capital funding will be given to (SHAs), to disseminate to local PCTs.

\section{Making the World Cup smokefree}

Health professionals across the globe are campaigning for a smokefree World Cup 2006 in Germany. The World Health Professions Alliance (WHPA) joins more than 170 organisations and alliances worldwide to support the UICC Global Smokefree Partnership's countdown campaign for a smokefree World Cup.

On behalf of the physicians, nurses, dentists and pharmacists of the world, the WHPA calls in an open letter to Fédération Internationale de Football Association (FIFA) for a reinstatement of a memorandum of cooperation signed by the World Health Organisation (WHO) and FIFA prior to the 2002 World Cup.

In the memorandum, WHO and FIFA agreed "that tobacco and sports do not mix and that tobacco in any form must be removed from all football events associated with FIFA."

It claims that as the World Cup will be televised internationally to billions of people, of all ages and races, it is important that the image promoted by FIFA is one that encompasses a healthy competitive spirit, not to be overshadowed by the unhealthy, life-threatening habit of smoking.

The WHPA supports the WHO Framework Convention on Tobacco Control, the world's first public health treaty which contains a host of measures designed to reduce the devastating health and economic impact of tobacco.

For more information visit www. globalsmokefreepartnership.org or www. whpa.org.

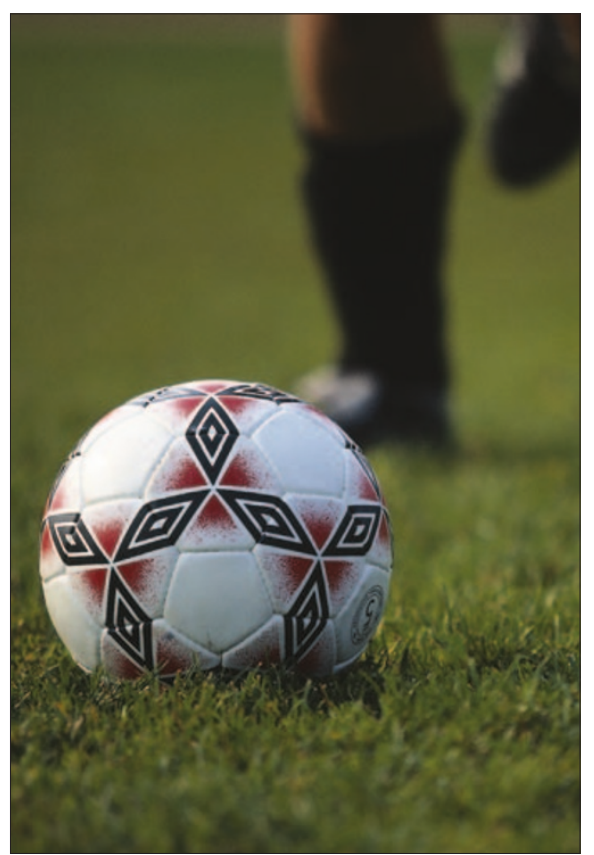




\section{New patient guide published}

The Faculty of General Dental Practice (UK) (FGDP(UK)) has published the guide Patients' Rights and Responsibilities, which sets out what patients can expect as part of their oral healthcare service, as well as the patient's own responsibilities.

The FGDP(UK) believes that it is important for patients - whether they are being treated in high street practices or in a hospital environment - to understand their rights and responsibilities in this process and the booklet explains what patients can do to help ensure they receive high quality care.

The guide includes patients' rights in terms of what to expect from their dental care professionals, information on decisions regarding treatment, how you are treated as a person during your care and information on cost of treatment.

Patient responsibilities include the manner in which staff and other patients are treated, appropriate disclosure of information, and attendance at appointments. Patients' Rights and Responsibilities is available on the patient information pages of the FGDP(UK) website at www.fgdp.org.uk.

\section{New Chairman appointed}

\footnotetext{
Dr Kathryn Harley has been appointed as the new Chair of Dental Protection's Board of Directors.

A Consultant in Paediatric Dentistry, she takes over from Brian Mouatt CBE who retires from the post in June. In addition to her recognition as a paediatric dentist, Dr Harley is soon to be appointed junior Vice-Dean of the Dental Faculty RCS(Eng) and currently sits on ten other administrative, academic and examination boards.

On learning of her appointment Dr Harley said, "I am honoured to have been given this opportunity to chair the board of Dental Protection. As the company continues to grow, the role and responsibility of the Board grows with it.

The Board's role is to ensure that the organisation stays true to its purpose of protecting and supporting its 48,500 members worldwide."
}

\section{Charity hospital wins research award}

Aniko Balazs, Dental Nurse Manager for the Royal Hospital for Neuro-disability, has been granted a Colgate-Palmolive Dental Care Professional (DCP) Research award for $€ 2,500$.

The Royal Hospital for Neuro-disability is an independent national medical charity based in Putney, southwest London. The hospital specialises in assessing and rehabilitating adults with traumatic brain injuries incurred through accidents or strokes. It also provides both treatment and long-term care for people with severe and complex neurological conditions, including Huntington's disease, multiple sclerosis and cerebral palsy.

The funds will enable support for the involvement of a dental hygienist to strengthen the current Oral Care Link Nurse scheme, which is in operation on all the hospital's wards. Aniko has worked at the charity hospital for just over a year. She said, "This award is incredibly important, both to the dentistry department and to the hospital as a whole. It will allow us to continue to improve our patient led care, and help us to work more easily in conjunction with ward staff."

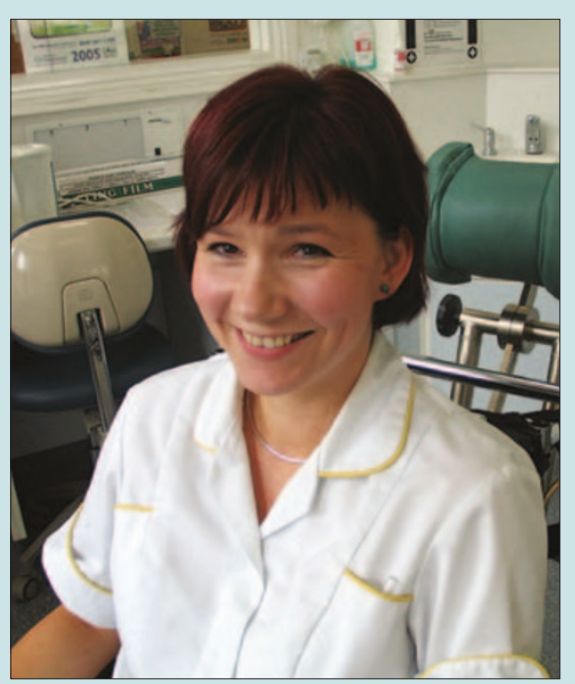

Award winner Aniko Balazs

The hygienist will work with the Oral Care Link Nurses to ensure that specific patient based oral hygiene programmes are developed, enabling patients to receive individual regimes that are specific to them.

The scheme also aims to make patient oral hygiene a daily routine of ward duties.

\section{Londoners too busy to brush teeth}

The hustle and bustle of city life may be causing Londoners to neglect their teeth, according to a survey conducted by the British Dental Health Foundation and HealthSure.

The National Dental Survey found that one in three people living in London admitted to never brushing their teeth for long enough, and this statistic was three times higher in London than in some places in the country and almost twice as high as the national average.

Dr Nigel Carter, chief executive of the British Dental Health Foundation, commented, "It is very worrying to think that people in London are struggling to even find the time to brush their teeth properly."

In the survey, only $11 \%$ of people in Southampton usually brushed for less than two minutes while other scores were: Newcastle (23\%), Cambridge (20\%), Manchester (14\%), Cardiff (14\%), Bristol

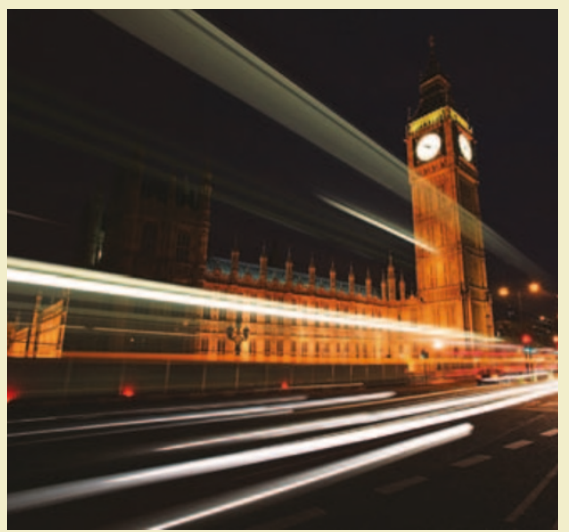

(14\%), Belfast (15\%), Nottingham (18\%) and Edinburgh (24\%).

The National Dental Survey was conducted as part of the National Smile Month (May 14 - June 13) celebrations and the Foundation and HealthSure are hoping people will use the campaign to consider how they can improve their current oral health routine. 